\title{
Culture and counter-culture ${ }^{1}$
}

\section{Anarchism: Terror and Utopia}

A curious paradox must be faced at the very outset: nothing is perhaps more culturally inclined than the various counter-culture movements. In other words, writing and working against the prevailing culture amount to an essentially cultural enterprise. Culture seems to be inescapable. A supposedly dying, declining or simply inadequate or wrong culture is usually criticized and fought against by a culture that is in a hurry to take its place. To use the famous formulation of Vilfredo Pareto, one could say that the whole human history is nothing but the ongoing struggle of a "repressed" élite against a power élite through a variety of means which can, however, be summarized and symbolized, as it were, by two animals, the lion and the fox, that is to say force and shrewdness.

A bird-eye view of counter-cultural movements could easily detect three main types:

a) a global approach, on the basis of which counter-culture would coincide with a total revolution, including institutions, governments, power structures, and individuals;

b) an essentially individualistic stand, to be convinced as a self-cultivating attempt in an alien or hostile world, bordering on some sort of self-exile in an environment which is dominated by an impersonal mechanistic logic and by industrial large scale machinery;

c) Finally, a reconciliation of humanistic values and culture with machines and technical progress, especially with electronic devices, to the point of inventing the new, programmatic word "cyberpunk".

The first type or phase is clearly defined by an approximately two century old anarchistic movement. Interestingly enough, such movement originates and develops mostly in countries characterized by a backward economy and a large illiterate peasantry. Zarist Russia and Catholic Mediterranean countries are its hot bed. No matter how strange it might seem, anarchist thinkers, while dreaming of a "powerless society", are in fact obsessed by power and its prerogatives. Even more strange that they should be concerned with power although they basically feel that power is more useless than obnoxious, because men are by nature good. The natural goodness of mankind and therefore the denial of any "original sin"- considered the main reason for the dogmatic teachings by the various religious churches - is the premise of anarchism. If men are by nature good, there is no reason to establish any kind power- be it religious or political or cultural or economic- in order to curb the instinctual drives of human beings. The need of society for government is only a tricky invention by those groups that are in a

\footnotetext{
${ }^{1}$ A first shorter version has been published by Lexington Books. F. Ferrarotti, Social Theory for Old and New Modernities: Essays
} on Society and Culture, 2007. 
position of social privilege. It is caused by the injustice and unreasonableness of the so called "social order" which should be overthrown and abolished.

Adopting an elementary Hegelian view of dialectic, anarchists, especially their pioneer thinkers, such as Kropotkin and Bakunin, feel that destruction will automatically create a new order, free from class divisions and social injustice. They believe in a total, radical revolution. Not all the anarchists, however, advocate violence to bring about the new society. Although they seem to be socialistically inclined, most anarchists differ greatly from the socialists. In fact, contrary to socialists, especially to those who have followed Marxist teachings, anarchists flatly refuse to work through legislation or government. They want to have property and therefore class distinctions abolished in such a way as to give individuals complete freedom of personal development in direct, mechanically unmediated contact with nature.

The official founding father of anarchism, Peter Alexeivich Kropotkin, a Russian Prince, trained first as a geographer, in 1872 visited Switzerland and joined at Geneva the Marxian International Working men's Association. He found it, needless to say, too conservative. Not unlike most anarchist agitators, his life was marked by an exceptional mobility: Russia, then Switzerland, Paris, England, the mountains of Savoy, and finally, quite like Marx and Engels, the peaceful and tolerant London as a safe haven and a permanent residence. Perhaps the gentle atmosphere of London, politically and socially speaking, was not without some positive effect on the mental climate of Kropotkin who, in his last years, became more and more interested in "mutual aid" and in writing up his thinking about agricultural and geographical subjects. With his insistence on a government as little as possible and on a grass roots inter-personal corporation as to make any social and political decision from above unnecessary, Kropotkin, in the most mature phase of his thinking, came incredibly close to the sociological theories of Herbert Spencer, especially as expounded in the book "Man against the State", not to mention the practical experiences of the British "Fabian Socialism" that could count on the efforts of such diverse personalities as George Bernard Shaw and Lord Beveridge. ${ }^{2}$ Despite his strongly individualistic stand, Kropotkin was not insensitive to the great myth of revolution as a mass, more or less "spontaneous phenomenon". Thus, when the Russian revolution, led by Kerensky and then by Lenin, broke out, he returned to Moscow where he died in 1921. Because of his relative solitude during his last years, Kropotkin can be considered, perhaps more than other well-known figures such as Michail Bakunin or the Italian Errico Malatesta, a key-thinker in the transition from anarchism, as a popular revolt against the established order, to a coherent individualistic approach, best represented by Leo Tolstoy, Henry David Thoreau, and Mohandas K. Gandhi, among others.

\footnotetext{
${ }^{2}$ As regards Lord Beveridge, see Voluntary Action, London 1945; among Kropotkin's works, are especially notable La conquête du pain, Paris, 1988; Sa philosophie, son ideal, Paris, 1896; Fields, Factories and Workshops, London 1899; Modern Science and Anarchism, London, 1903; Ethics, Origin and Development, London, 1924.
} 
The single most distinctive feature that differentiates the first type of counter-cultural movement from our second type is perhaps offered by anarcho-syndicalism. This is essentially defined by its declared intention to support in every way group militancy, including revolutionary violence and civil war. In a sense, this special kind of violent counter-culture covers almost a century and a half of European and American history, ranging from the organized groups in France, Spain and Italy at the end of last century to the insurrectional traditions of Latin America and to the "Black Panthers" in present day United States. ${ }^{3}$ This peculiar brand of anarchism would not refrain from attempts on the lives of socially and politically prominent individuals in order to spread terror through the so called technique of the "exemplary action". Assassination was considered a normal political weapon.

The overall justification was found in the duty to resist oppression and its representative personalities. At the turn of the century such ideas resulted in the killing of M. F. Carnot, president of France; Elisabeth, empress of Austria; Humbert I, King of Italy; William McKingley, president of the United States. Although the specific situations are largely different, one could also mention the murder of President John Fitzgerald Kennedy in 1963 and of Italian former of Prime Minister Aldo Moro in1978. Motivations differ and political situations are not comparable, but the profound intent is always the same: to kill one in order to "educate" many, that is to provoke a large scale shock throughout the social, political, and cultural community and raise doubts about the commonly accepted culture and the conventional wisdom.

Although anarchism, as we have mentioned above, was mostly active in Southern European countries and in Latin America, one of its early presentation was given by an English thinker, William Godwin, who advocated not only the "whitering away of the State", as it was later proclaimed in the "Communist Manifesto" by Carl Marx and Friedrich Engels (Brussels, 1848) but emphasized the need for a network of small autonomous communities and for a communist distribution of private property in a Stateless society. ${ }^{4}$ His attitude toward technical progress was ambivalent and quite vocal, to the point of inducing him to say that the whole food needed for mankind could have been grown in a flower vase. In this respect, anarchism and utopian dreams would join hands.

Despite the general individualistic bent and the emotional hatred against the State structure and public bureaucracy, the central problem for anarchists remained the problem of power acquisition.

\footnotetext{
${ }^{3}$ The link between Anarcho-syndicalism and Socialism is, however, historically established; see, for instance, George Sorel: Tout l'avenire du socialism reside dans le developpement autonome des syndicats ouvriers in G. S., Materiaux d'une theorie du proletariat, Paris.
}

${ }^{4}$ Cf. W. Godwin, Enquiry Concerning the Principles of Political Justice, 2 vol. London, 1793. 
Even the French social thinker, Pierre-Joseph Proudhon, author of the famous pamphlet "Qu'est-ce que la propriété"? and of another equality famous book on "La philosophie de la misère", against which Marx would twice write a savage attack in "La misère de la phisolophie", was obsessed by power, especially by State centralized power as the denial of the basic principle of justice. In his view, justice meant and required a state of balance. This could be implemented only in a federal form of society, based on a limited right of possession and in which any power would be checked and controlled by a countervailing power in a system of permanent equilibrium which he called "mutualism".

Nothing could be farther from the doctrine of Thomas Hobbes who would see the legitimacy of the state and its central power in its protection of every citizen as regards the fear (metus) of violent death. On the other hand, the problem of power which seems to haunt all the socially and politically oriented anarchists cannot be dispelled and even less resolved simply in moralistic terms

\section{The central importance of the question of power.}

It is instructive, and perhaps has a significance greater than that which is generally recognized, that the question of power raises first of all, the question with which every detective story worthy of respect opens: Who did it?- or- Who is the guilty party? In terms which are perhaps more appropriate, one might say: Who holds power?; Who is the object of his decisions?; Who is the actor?; Who submits? We are here at the heart of any counter-culture movement.

However, it seems clear that these famous questions, which pop up in "State and Revolution" as also in all Lenin's political writings - Lenin, probably the first professional revolutionary in the absolute sense-cannot point to a rigorous dichotomy. ${ }^{4}$ In fact, the actor, who decides and acts, in his turn necessarily undergoes the reaction to his actions, is aware of the direct or indirect braking effect in terms of passive resistance or active mutuality, which the object of the decision-making process sets against his decision. Even when the decision was taken in the interests of the object, and is thereby accepted and even wished for, the pure and simple practical discharge runs up against and has to come to terms with a braking action which is natural in the very complexity of the society.

It is clear that the question of power is a central one in every human society. This central position is first of all linked to the precariousness of the conditions of individual autonomy which seems characteristic of any human coexistence, even only moderately developed. George Simmel grasped this point perceptively, when he remarked that, the toughest problems of modern life derive from the attempt of the individual to preserve the independence and individuality of his existence against the sovereign powers of society, against the weight of historical patrimony, of external culture and technique of life. 
However, John Stuart Mill, in the third and fourth chapters of "On Liberty", had already with adequate clarity established the terms of the complex relationship between individual autonomy and the power of society. In fact, Mill never speaks of power but rather of authority. On the curious interchangeability of the two terms "power" and "authority", which characterizes modern studies on sociology and political science as well as on the conceptual confusion which corresponds to this, will be necessary to return, since in my view we are not dealing with a mistake caused by occasional sloppiness, Schlamperei which seems to afflict even the most attentive scholars, so much as with a valuable linguistic spy hole which introduce us to the shadowy realm of today's theoretical and political discourse.

It is rare to find in sociological literature and in that of social philosophy such a passionate hymn as that voiced by Mill in praise of the "individuality of the individual". In his words there is an extraordinarily penetrating anticipation of current criticisms of mass society, leveled down and one-dimensional, which in particular Frankfurt school and even more, in the writings of the contestation of ' 68 , were to make popular even among those journalists, most scrupulous regarding the banalities of the day, and among less demanding readers. Nineteenth century China, static and closed within its traditional and ritualized behavior, was for Mill the negative model. This negativity was attributed to the suppression or the simple diminution of individuality, the taste for diversity and eccentricity. According to Mill, the Chinese, though endowed with "much talent", had become stationary and remained so for thousands of years, as Europeans would become too, if English philanthropists, lovers of general leveling down, were they be successful. In a vein which recalls Tocqueville, Mill observes that "the modern regime of public opinion is in a disorganized form, while the Chinese scholastic and political system are in organized form; and the less individuality manages to affirm itself victoriously against this yoke, Europe, despite its noble precedents and its professed Christian faith, will tend to became another China".

Raising the problem which was to be at the basis of Ernest Troeltsch and Max Weber's concern, Mill asks himself what made the family of European nations an improving, instead of a stationary, portion of mankind. Mill's reply is clear and without reservations. European development is not to be attributed to a superior "excellence" of Europeans, an excellence which, according to Mill, would in any case be an effect and not the cause of their progress.

Rather, the cause should be sought in their "remarkable diversity of character and culture". Mill sees the danger in the constant reduction of this diversity, this "plurality of paths" towards development, and in the flattening, both cultural and existential, which necessarily derives from it. "However large the differences of position which remain", he notes, "They are nothing in relation to those which have ceased. And assimilation is still going forward". 
One cannot say that John Stuart Mill's fears are completely without foundation. However, what must be clarified is that Mill does not see a basic point, that is he does not take into account that the problem of the individual is not and cannot be resolved and strictly not even set out in its real and meaningful terms as an "individual fact". This problem is far from unrecognized in the social sciences. The relation of individual-society returns in a recurrent, almost foreseeable fashion, in the history of the social sciences. After every phase dominated by objective, "positivistic" and structural concern, almost by a conditioned reflex, one returns to a phase of "reflux" in which, with overriding force emerge and bring themselves to the attention of scholars and average informed public opinion the questions of the subjective private and the personal. Once more the tension between two poles of human experience, the individual and the social, is inflamed and tends to increase. It thus happens that one forgets the indissoluble connection between two poles. As I have recently had occasion to note elsewhere, this phenomenon is far from unheard-of. It is enough to think of the long polemic which set Emile Durkheim against Gabriel Tarde as the primacy of the psychological individual element, or of the social collective one, in the constitution of society. Formulated in these terms, the question runs the risk of seeming banal, as though we were dealing with an internal polemic, an expression of academic quarrelsomeness if not of mean personalisms.

\section{The struggle against power and the prevailing culture as withdrawal within the inner soul.}

It is fascinating to consider that the constant struggle against power and its cultural defenders is likely in the end to result into a mirror like counter-power without being able to get out of its logic. It seems to be an exquisite case of contamination through contact. The only alternative to a risky power struggle seems to be the pure and simple renunciation with its inevitable consequence: the withdrawal from the external world into the inner soul of the individual.

Already the history of anarchism provides some excellent examples of such withdrawal, not to mention the whole tradition of the ascetic hermits during the tumultuous transition from the last years of the Roman Empire to the early stages of the Middle ages. The case of Saint Jerome, who retires from his native Dalmatia to a cave near Bethlehem in order to escape temptations but also to translate in the latin of the "Vulgata", the Holy Scriptures from the Greek text of so called "Seventy", is known and more than once celebrated by the Italian Renaissance painters. The situation is, however, different when we come to the modern counter-cultural movements. Here, the withdrawal does not have, as it were, a superior justification. It is not the attempt to sanctify oneself and to open a special personal avenue for communicating with God. Rather, it is a rejection of the external world in order to achieve peace and clear conscience with oneself. Instead of denying the individual in front of Divinity, it is a 
refusal of the world to be able to know and to appropriate the value of individual per se, without the need of transcending him. ${ }^{5}$

The representative "hero" of this phase is undoubtedly Michel de Montaigne. I have elsewhere remarked that the great individual of the classical age, Ciceronian and Plutarchian, fulfilled himself in the service of public office. Saint Augustine's Confessions are justified by a self-improving purpose. Montaigne's ego felt no need for one. Indeed, he pointed to public responsibility as an objective obstacle to his own fulfillment and any intention of doing good was foreign to him. Historically, it was perhaps the first time the ego of an individual, a private citizen, was considered so important as to warrant a long, daily exploration.

One might say that Montaigne was living out the ideal of "otium" contrary to "negotium". A kind of living on self-demand, free from any social or cultural obligation that might remind the young reader of today of Kerouc's On the Road or of the movie Easy Rider. But for his lifestyle, Montaigne did not claim any exemplary value. Contrary to Saint Augustine or Rousseau, in his Essays Montaigne did not have any edifying purpose in mind. He refuses to set an example because he is convinced of the relative value of all the truths and of the inner fragility of the individual itself. He simply wants to record his own changing spiritual position, the internal motions of his own soul. This gives him pleasure. ${ }^{6}$

The stand taken by the pacifists belonging to nonmilitant counter-culture movements is quite different. While alien to any organized movement and strongly individualistic, their position tends to be an example for everybody. Their militancy is purely ideal. It abhors organization ties or discipline of any kind.

In a sense, they are rather close to the romantic idea of the intellectual as expounded by Herman Hesse in his book Der Steppenwolf, although their lifestyle and selfexpression will basically depend on their original culture, no matter vitriolically criticized and finally rejected.

\section{H. D. Thoreau: the hero of the Walden.}

Three writers seem to stand out as meaningful case studies of the second type of counter-culture: Henry David Thoreau, American, the German thinker, Johann Gaspar Schmidt, better known as Max Stirner, and an Italian poet and novelist, not to mention his exploits as movie-director and actor himself, Pier Paolo Pasolini. Different as they are, they all share a basic attempt to transcend their original cultural environment. Within the framework of American way of life, Henry David Thoreau can most certainly

\footnotetext{
${ }^{5}$ In this connection, and for a general survey, cf. Weintraub, The Value of the Individual, Chicago, University of Chicago Press,
} 1980; Jean Starobinski, Montaigne en movement, Paris.

${ }^{6}$ Cf. My Five Scenarios for the Year 200, New York, 1986, p. 106 
be regarded as a representative champion of counter-culture as a strictly individual enterprise.

He is the celebrated author of Walden, a booklet that contains the diaries of the two years he lived in an absolute solitude near his native town of Concord in Massachusetts. Thoreau's style, contrary to the highly philosophical one of Max Stirner or the flamboyant,one of Pasolini, is extremely dry and simple. What strikes the reader is the pragmatic nature of his existential experience. Thoreau never speculates on a theoretical level, nor he seems to indulge to what he would probably have considered idle thinking or a pure waste of time, even when he expresses his polemical stand and tries to justify his counter-culture posture.

Of course, he is fully conscious of going against the American grain, but he simply lives day by day according to his beliefs in a practical way, quite faithfully following the pragmatic and non-abstract trend of his original American culture. His critique of the way his fellow-countrymen live is, however, radical. Hi does not only contest some basic orientations such as the desire for prosperity or the personal victory over jealous competitors. He attacks what have come to be considered essential services of any civilized society, such as the post-office and the railways. He writes in Walden: "Men think it is essential, that the Nation has commerce and export ice, and talk through a telegraph, and ride thirty miles an hour, without doubt, whether they do or not, but whether we should live like baboons or like men, it is a little uncertain. If we do not get out sleepers, and forge rails, and devote days and nights to the work, but go to tinkering upon our lives to improve them, who will build railroads? And if railroads are not built, how shall we get to heaven in season? But, if we stay at home and mind business, who will want railroads? We do not ride on the railroad; it rides upon us".

This might easily be regarded as a polemical trick, a reduction "ad absurdum" which ignored the facts of life and its practical necessities. For instance, the need to go somewhere in a hurry and not for fun; often, our presence is required by a family member who is not well or on account of some important business that cannot be postponed.

The rebuttal of Thoreau is again quite stringent. "Why should we live with such a hurry and waste of life?", he asks himself. And the answer he offers is clear: "We are determined to be starved before we are hungry. Men say that a stitch in time saves nine, and so they take a thousand stitches today to save nine tomorrow. As for work, we haven't any of any consequence. We have the "Saint Vitus' dance, and cannot possibly keep our heads still".

The motion of what a good life is for this individual anarchist emerges very clearly. It is a life free from obligation of any kind. His ideal is to be able to live frugally with very little to the point of being able to live, like a new-born baby, on self-demand. Why 
did he withdraw from the civilized world? Here is his answer: "I went to the woods because I wished to live deliberately, to front only the essential fact of life, and see if I could not learn what it had to teach, and not, when I came to die, discover that I had not to live. I did not wish to live what was not life, living is so dear; nor did I wish to practice resignation, unless it was necessary".

This is certainly a very revealing passage. Thoreau seems obsessed with the idea that most people come to die without having ever been really alive. His stand is not so much against large scale mechanization, as his attacks against the railroad might imply, as against consumerism, that is to say against the buying and selling of so many material objects as to be in the end submerged by them. A multitude of objects for him does not mean wealth or comfort but rather suffocation, loss of consciousness, falling into a profound sleep that makes one unaware of what is really important. Machines are bad and to be disposed of, but even worse than machines is the attitude that forces one to lose self-conscience by relying too much on objects that make you sleepy. For Thoreau, nothing is superior to the direct contact between man and nature. He emphatically asserts, "It matters not what the clocks say or the attitudes and labors of men. Morning is when I am awaked and there is a dawn in me. Moral reform is the effort to throw off sleep... We must learn to reawaken and keep ourselves awake, not by mechanical aids, but by an infinite expectation of the dawn".

Whoever reads and reflects upon this life program cannot help feeling that Thoreau not only aimed at a total self-sufficiency but that he would go as far as denying the benefits of civil society.

Talking to himself was for him enough of conversation, but it seems difficult to deny that, at least for most people, no man is an island and no kind of counter-culture can be built upon the total denial of the previous culture without jeopardizing its own roots and historical justification. The portrait of Thoreau as depicted by Ralf Waldo Emerson, while full of admiration for his subject, gives a hint of some serious reservations: "He was a protestant, an outrace, and few lives contain so many renunciations. He was bred to no profession; He never married; He lived alone; He never went to church; He never voted; He refused to pay a tax for the state; He ate no flesh; He drank no wine and he never knew the use of tobacco; and though a naturalist, he used neither trap nor gun. He chose wisely no doubt for himself, to be bachelor of thought and nature. He had no talent for wealth, and knew no to be poor without the list hint of squalor or inelegance. Perhaps, he fell into his way of living without forecasting it much, but approved it with later wisdom". Emerson sums up his portrait saying that Thoreau "chose to be rich by making his wants few", but at the same time he cannot help noticing that "there was somewhat military in his nature, not to be subdued, always manly and able, but rarely tender, as if he did not feel himself except in opposition". ${ }^{7}$ 
Here we have a common trait of all the counter-culture movements. Despite the fact that these movements do not intend to be militant, that in their individualistic form they tend to withdraw rather than to fight, and that, while opposed to the government in power at the moment, are equally opposed to every class of social reforms, they seem to attract sympathy and a certain amount of followers, especially among young people. In this sense, there is a symptom in these movements, despite their extreme individualism and aloofness, to turn into a mass movement in the form of a huge international contestation, by students and young people in general, against the "system".

\section{The Individual against Society.}

Let us now turn to consider a figure who is contrary and symmetrical with respect to Thoreau. In fact, Max Stirner is as individualistic as Thoreau but his main preoccupation lies in the elaboration of a firm philosophical foundation for his personal position. He belonged to the left wing Hegelian School in Berlin, did not live a long life, barely fifty years (Bayreuth 1806-Berlin 1856), and being "vir unius libri", that is the author of only one famous book, owed, strangely enough, most of his fame to the sarcastic attacks by Karl Marx and Friedrich Engels, who would call him Saint Max, the Holy father of the church, and also Sancho Pansa, caballero andante, and Jacques le Bonhomme. Irony aside, I feel that Marx and Engels, who were not inclined to waste time with petty criticism, must have realized that in Stirner's writings there was, hidden away under a heavy philosophical jargon, a basic argument against the Marxian theoretical construction.

The idea of Stirner that an inescapable transcendent element was to be present in any revolutionary, or utopian, social theory was certainly in itself a powerful objection to a system that pretends to be wholly historically "immanent", as Marxism. Actually, already in his early criticism of Ludwig Feuerbach, Stirner attacks human sanctity as being more dangerous than divine sanctity because the fact of being pious on the part of confessed atheists constitutes in the end a more intimate form of piety than the one professed by believers precisely because immanence represents a more intimate religiosity than transcendence. Stirner used to say, not incoherently from his point of view: "Our atheists are very pious people". These are not only abstract or purely theoretical propositions. They touch on the basic issue as far as Stirner's thinking is concerned. They involve the question of the independence of the subject.

Whereas Thoreau would criticize and refuse to have resort to the main services of a civilized society, including railroad and the post office, and would therefore keep his overall protest on a very practically level, it is typical of Stirner to take the same position but from a distinctively speculative standpoint. In Der Einzige he states quite flatly: "All the truths under me we are dear; a truth above me, that is truth according to which I must direct myself, I do not recognize. For me there is no truth because 
above me nothing has any value. Not even my essence, not even the essence of man is higher than myself".

In this sense, the conception of the Einzige coincides with the "Ego", not with the general spirit, and the "Ego", who does not recognize anything above itself, can use its property. Based on this general conception, Stirner develops, not only against Hegel but also against Marx and Engels, a special "human dialectic". In his view, Hegel's dialectic is totally abstract and filled with historical experience only in accordance with a preconceived notion of the actual historical development. In this respect, Stirner does not miss the opportunity of leveling a keen critical remark against the intellectualistic approach of Descartes. This approach, beautifully summarized in the famous "cogito, ergo sum", has been conditioning the whole "scientific" development of modern thought in the sense that one can talk about existence only within the gnoselogical framework, that is to say only when one thinks.

It is from this kind of criticism that we can gather the existentialists' nature of Stirner's philosophy. Perhaps earlier than Kierkegaard and Nietzsche, Stirner emphasizes the limitations of a way of thinking that would ignore, in favor of abstract reason, human sentiments and emotions.

Thoreau was searching for his own independence in a coherent denial of what he considered useless social amenities and cumbersome comforts. Stirner, quite Germanic in this respect, does not seem to be satisfied with a purely practical solution, no matter how effective. He looks for a philosophical one. The question is: How can we obtain and guarantee the authenticity of the Einzige?

The key-word in Thoreau is "self-sufficiency". In Stirner the key-word is "authenticity". The Einzige, a word that I would like to translate as the "absolute individual", can be fully authentic only if and when he is capable of implementing his own "revolt" (Emporung), not to be confused with "revolution" (Revolution) which is an ideological and political term, implying the action of huge masses of people led, that is to say enslaved, by self-appointed leaders and self-styled "revolutionaries". In a stoic vein, which makes him quite congenial with Thoreau, Stirner does not advocate a revolution, nor he plans to excite the masses. He just asks the individual whether it is convenient to him to obey the established laws, and thereby to give up his authenticity, or to follow his own personal law which is the basis and the condition to be fully authentic. It is clear from this point of view that Stirner had to be considered an anarchist, although, as we have seen, even anarchism would seem to him not enough individualistic. No society can be authentic and social living is in itself the complete denial of individual authenticity. Contrary to Marx, Stirner time and again dwells on the intrinsically anti-individualistic nature of society. The right of the individual is essentially against and denies the right of society. The state, on the other hand, is nothing more than a 
bureaucratic arm of society, and as such it is the archenemy of the individual. Stirner could not be more explicit on this point: "What is called state is a tissue and a complex of dependencies and affections, it is a solidarity, a reciprocity, in which those who are organized together resign themselves to live together, in one word, they depend on one another: The State is the order of this dependency". The logical consequences are evident: "The Ego of the People is a Ghost, not an Ego". And as regards the State: "I am the mortal enemy of the State; it cannot escape the alternative: "itself or Ich ("Ich bin der Todfeind des Steates, in der Alternative schwebt: Es oder (ch")".

Needles to say, this mortal hostility between Enzige and the state does not call, nor require a revolution. It requires a stoic, coherent, firm "revolt", that is an intimate, almost ascetic, rejection and withdrawal. This amounts not only to a change of external conditions, as in the case of the revolution, but to a "mutation" (Unwandlung) that does not depend on the existing social situation. It rather depends on an internal human dissatisfaction (Unzufriedenheit der Menschen) that finally emerges as a subjective, individual rebellion (Erhebung des Einzelnen) totally careless about its practical consequences. Summing up his thinking on this key-point, Stirner says: "Revolution commands to create institutions; the revolt requires the individual to rise himself higher".

Given such philosophical position, how is it possible for Stirner to escape the charge of being logically obliged to fall into the trap of an absurd solipsism? The answer offered by Stirner on this crucial point, is not very clear. It reflects the ambiguity of an extreme individualism that considers society and State as mortal enemies while at the same time it is aware that, without such enemies, even its self-consciousness would vanish. Not by mere chance Stirner rejects the charge of solipsism and underlines the fact that he only tries on an ethical level to prevent that the authenticity of the Einziger might get lost through the close contact with other individuals.

In all the different forms of historical societies, Striner detects a loss of authentic dimensions of the individual and obviously of his property; however, he is far from renouncing to a social living, to some sort of living together, because he feels and explicitly states that the original condition of human beings is not total solitude or loneliness (das Alleinsein). The bond of everybody with one's mother since birth and the care and affection which everybody experiences in early childhood as a basic condition for survival and development do not escape Stirner's attention. It is difficult to deny that Stirner has here a profound contradiction. What he seems to have in mind is a kind of association which would go beyond the established society we all know, with its rules and regulations impinging upon the creative freedom of the individual. This freedom, however, needs exchange and cross-fertilization with other fellow-members of the society. Stirner's general conception does not seem to be able 
to lead us out of this impasse. His counter-culture position, as radical as it is, remains within the framework of the traditional culture it is supposed to attack and replace.

\section{Ethical Problems transformed into Aesthetic Attitudes.}

After the hermit Thoreau and the philosopher Stirner, we finally come to the poet, Pier Paolo Pasolini. He was quite definitely against the culture, as well as the political Italian establishment. Especially in his articles in the "Corriere della sera" he would voice his radical critique of all the major institutions, from the school system to Parliament, to television and in general to consumerism, that he considered responsible for having "robed", the Italians of their traditional "frugality" and peasant simplicity and authenticity. In this vein, one could consider Pasolini as a neo-Franciscan preacher although he would motor around in a deluxe car and would not refuse the hospitality of first class hotels. He seemed to be in love with the extreme "poverty" of the Roman slums, at the periphery of the city. Mostly for this reason he was regarded as the typical committed intellectual. To support this view, emphasis was usually placed on the tough, disenchanted nature of the wicked stories of the borgate. I think this was a mistake. Pasolini in his fiction showed he was in a hurry to set down the facts, dialogue, environments to give himself over, as soon as possible, to those Handelian largos where the poet seems to catch his breath, and which seem to closely resemble in their coolly bucolic, calm tones, the "diaries" of Gregorovius, as he climbs, alone and on foot, towards Tivoli on a May morning. On everything and everyone there floats an even, free, smiling luminescence. Despite the poverty, the evildoings, the thefts, the vilest trades, prostitution, trickery, violence and death, there is the untroubled, stable air of static, pre-industrial ages, defined as the "eras of acceptance" before competitive clashes and mass bureaucratic organizations. There is the air, still human, and deeply personal, a picaresque good-nature, naturalier optimistic after every disaster, and well disposed towards its neighbor and towards life.

For example, in Ragazzi di vita: "It was early evening, and a fine breeze lightened the atmosphere at the time the workers were coming home from work and the trams went by packed like tins of anchovies, and you had to wait three hours under the shelters to be able to get to hang on the steps. From San Lorenzo to Verona and on to Portonaccio, there was a festival, a hugger-mugger, a thronging, Riccetto sang ear-splittingly, "How beautiful you are, Rome, How beautiful in the early morning", completely reconciled to life, full of fine projects for the future, feeling the cash in his pocket.

Or again, from the big Dome behind Ponte Sisto, to Tiber Island behind Ponte Garibaldi, the air was as tout as the skin of a drum. In that silence, between the great walls which stank like urinals in the heat of the sun, the Tiber flowed yellow, as if it was driven on by the rubbish it came down filled with..." 
Here, behind the transfiguration produced by Pasolini's typical magical realism, against the appearance of the evidence of a simple sociological document which does not shun and indeed certainly revels in its coarseness, there rings through the distant sound of the Flavus Tiber, reaching us intact through the training of a culture remaining, ultimately, humanistic. Pasolini re-unites this to the present poverty, with an intention that apparently wishes to desecrate it whilst it reveals the sadness of an unconscious nostalgia.

Even when he proposes documenting and reasoning, Pasolini "shudders" according to Goethe; it is in "shuddering" (das Schaudern) that the best of man lies. But it should not be forgotten that this trembling is also the way whereby ethic-political problems are reduced to aesthetic-existential attitudes. This limitation, so clear in Pasolini when one considers him as a witness-sociologist and, on the other hand, so characteristic of the Italian intellectual has been understandably eclipsed by his tragic death and the emotional reaction following it.

It may be that Alberto Moravia was right, and that Pasolini should be considered as the civil poet "of the left" of modern Italy, laid waste by a senseless development and robbed of its profound cultural identity by a political class dominated by the "politico-business-judicial complex", as consistent as the "military-industrial" complex J. K. Galbraith wrote of in the US. But than one must admit that the poet suffers and reflects this reality in so exact a way as to be its accomplice. Moravia states that the novelty of Pasolini is that civil poets in Italy have been always of the right. My view is that Pasolini, if you want to see him as a civil poet, cannot be strictly termed either of the right or of the left. He simply fits into the furrow of the traditional civil vocation of the Italian intellectual, summoned to celebrate myths ${ }^{8}$, much more than to collaborate in a rational project of community development, and only in exceptional cases ready to make himself intransigent and logical bearer of this to the point of martyrdom (Giordano Bruno, Piero Gobetti). In this sense, the civil vocation of the Italian intellectual as it is passed to us by literary tradition cannot easily evade a heavy conservative, regressive character. As civil poet, it seems to me that Pasolini should be placed between the Carducci of "Per la morte di G. Garibaldi" and the Pascoli of "La grande proletaria si e' mossa". Re-reading "Le ceneri di Gramsci" and "La religione del mio tempo", despite the at-times heated and even insurrectionary tones, especially in the later "piratic" interventions, Pascoli would seem close to Pascoli and his "poetics of the young boy": ambiguously undecided between faithfulness to values and to the joys of an indeterminate nature and entry to the adult world of history. "Le ceneri di Gramsci", rightly considered one of the highest achievements of Pasolini's poetry, has undoubtedly twilight, echoes of a decadence more homegrown (Guido Gozzano, Sergio Corazzini), than European. The evening at Testaccio, the lights in the windows 
at dinner time... One thinks of the final verse: "Life is buzzing, and these lost in it, lose it calmly, (if their hearts are fed up with it; wearing themselves out $\backslash$ here they are, wretched, of an evening : and powerful in them, defenseless, for them, the myth \is reborn ...But I, with heart aware \who has life only in the story, \will ever be able with purer passion to operate, $\backslash$ if I know that our story is finished"?

This theme of vital concreteness constantly returns in Pasolini's work. The concreteness is perhaps superior to any historical project which, by being willed and deliberate, already reveals itself as an artificial construct, whereas the vitality is more deeply rooted and essential. This theme is like a ground bass, goading and tormenting him like an ever open wound that never stops gushing blood. Then, also there is his obsession with the "machine", so typical of the recently urbanized provincial: wealth and poverty as states of mind; love-hate for the bourgeois order; the cleanliness of a well-ordered house; and finally affinity beneath the skin with the aristocratic predators in a prebourgeois city like Rome, and the mutual attraction of extremes.

For example, we have the aristocracy as meta-historical caste and the sub-proletariat of the periphery as a new, natural aristocracy not yet entered into history.

The name of Curzio Malaparte comes to mind. The author of II sole è cieco, Kaput, and La pelle, but even earlier, at the time of the first world war, of L'Italia barbara, and La Rivolta dei Santi Maledetti, was perhaps a "hidalgo", not unconnected with Pasolini's work and human trials. These connections exist both in terms of their variety of political affiliations, and a certain vitalistic versatility: cinema and the mass media - even though technical considerations did not permit Malaparte to be a real director. They have in common something theatrical and deliberate, in their character of the highly bourgeois taste to "épater le bourgeois", perennial Rastignacs out to conquer a Paris that perhaps does not exist. What Raffaello Brignetti says on this seems very penetrating: "Essentially a Bellian... that does not mean his talent was not also at times Shakespearean, Plautan, Gramscian, Christian, tragic, fairytale, Gidean, dialectal, D'Annuzian. But not Gaddan, however. Certainly, with his own share of genius, but without the great weight of genius, the 'where', the centre of moral gravity. It was the genius of the mugging, of avidity and good timing, always the same as those who are most thirsty for assertion, for life". ${ }^{9}$

This interpreter is sharp, but reductive - as a simple comparison and the assertion of essential affinity with Malaparte would be. So too, in some ways, with his voracious book-consuming auto- didacticism and ultimate visceral patriotism of Italia mia, a comparison with Giovani Papini would be. There is a whole essayist side to Pasolini which should be explored, and which forces us to question ourselves about the nature and quality of his civil vocation. Such an examination, which suspends severe skeptical

${ }^{9}$ R. Brignetti, Interpretazione di P. P. Pasolini, “Corriere del mezzo giorno", 5 January,1977. 
questioning about his most explicitly progressive pronouncements, may appear to the superficial observer and the strict Pasolinian to be an act of sterile, moralistic accusation.

From a technical view point, what is striking in Pasolini's work with a social inspiration is his use of metaphor. He sometimes thought of himself as the "restorer of Logic". The way he promoted this qualification, in the epitaph to himself in "Poesia in forma di rosa" concerning his career as poet, and with a prophetic glance at the sea of future millennia, is captivating but unacceptable:

"I came to the world at the time/ of the Analogic/I worked/in that field, as apprentice. / Then there was the Resistance / and I/ Fought with the weapons of poetry. / I restored logic and was a civil poet."

Certainly one cannot say logic is absent from Pasolini's writing. But if we accept that the procedure of logical discourse is a sequence that passes, coherently, from clear and scientifically relevant formulation of the problem, then enunciates an explanatory hypothesis and finally submits that to tests, we must acknowledge that the logical structure of Pasolini's argument is presented in a stimulating but mostly misleading way. It does not start from the clear definition of a problem, open to all to check according to the logical canons that make scientific discourse a public procedure, but rather from the fulminating and often brilliant formulation of a metaphor ("Prima della somparsa delle lucciole" the "The palace of Power" etc).

From this Pasolini often goes on to derive a series of corollaries, with his concise deductions, which are socially and politically impressive. However, they have one difficulty. They are not linked to a clearly defined and thus rigorously analyzable and ultimately explainable problem, on the basis of methodological rules open to inter-subjective examination, checkable by all.

For Pasolini metaphor is not an aid to discussion, as it has been for the whole pedagogic cultural tradition. In Pasolini, metaphor is the spring board, the point of clarity for his reasoning. Even when he agreed with Goethe's judgment that "Alles Vergagliche ist nurein Gleichnis" ( everything that exists is only a reflection), it is certain that the metaphor is called on to clarify, not to replace thoughts. Its purpose is to make it more transparent, easily graspable with comparison, similarity, analogy and allegory. It is a pedagogic aid to the logic of the argument. In Pasolini, on the contrary, metaphor is the brilliant substitute for logic. I do not purpose to apply Nietzsche's cruel, profound aphorism to his case: "Metaphor makes thought unnatural, sterile (it does not grow alongside), and in the end empty of thought". However its true that once metaphor has replaced analysis with a kind of indefinite, prophetic contraction, Pasolini draws all the implicit corollaries with iron cohesion, and quite quickly reaches an inevitable result. This takes the form of a civil, political critique as impetuous and total as it is 
socially irresponsible and suffused with unconcerned, aristocratic distance. This point seems to me important. I repeat it here because I had the chance to make it directly to Pasolini during a TV program in which, unfortunately, the TV directors found the multifold first levels of his mask more interesting than the logical and the political substance of the debate. This as usual was sacrificed to the so-called 'public taste'. In fact, this explorer by night of the roman "Borgate" in his Alfa Romeo GT 2000, made the search for his personal, private pleasure systematically coincide with a public, political mission. It is the ancient vice of the Italian intellectual which once again stands out: the world and its problems are reduced an occasion for "bel canto".

\section{Counter-culture as an individual and Social Liberation from the Impersonal Imperatives of a Technocratic System.}

Especially in the late sixties of the last century, a most powerful and vocal counterculture movement has taken place among young people of the western world, particularly among university students. The causal or conditioning matrix of the movement was highly articulate and different, ranging from the refusal of the Vietnam war in the United States to the frustration bred by a lack of political opposition in western Germany, the anti- paternalistic feeling in De Gaulle's France and "baronial", authoritarian atmosphere in the universities and in the society at large in Italy. Different as they were in their proximate causes, the various youth and students' movements coincided as far as some broad features were concerned:

1. A radical protest against the "establishment", that is to say against the adult world as organized and ruled by their fathers and by those professors in the school system who would be seen as "father- figure",

2. A militant stand against the prevailing system of thought and against the practical set-up of production and consumption, seen as being "soul-less", purely mechanistic and impersonal, exclusively geared to material wealth and greed;

3. A denunciation of traditional values as being "empty" and a thrust toward authenticity and spontaneity, believed to be the only acceptable source of moral obligation and capable of returning to man that essential "plasticity" and "multivalence" that had been taken supposedly away from him to the point of reducing him to a pathetic "one-dimensional man". ${ }^{10}$

Contrary to what was expected also by deft social analysts, such as Edgar Morin and Alain Touraine ${ }^{11}$, the counter-culture movement of ' 68 did not amount to a social and political revolution. Although intermittently inspired by the "cultural revolution" of the Chinese Red Guards against their own "bureaucratization" - a "revolution

\footnotetext{
${ }^{10}$ The reference is here made to the famous book by Herbert Marouse, The One-dimensional Man, London 1964, a genuine livre de chevet for the 1968 generation. Needless to say, the myth of "total authentioity" had already been fully expounded by Max Stirner, as we have seen, approximately a century earlier.
}

${ }^{11}$ Cfr. E. Morin, La Brèche, Paris 1970: A. Tauraine, Ce n'est qu'un début mai '68 ou le comunisme utopique, Paris, 1970. 
within the revolution" was the catchy definition offered by Régis Debray - the '68 movement could never overcome the fact that it was mostly made of urban middle class students who would support themselves on the monthly check received by their families. I do not think it would be fair or empirically demonstrable to reduce the whole contestation movement of ' 68 to a purely psychological question of frustration derived from protracted dependency on parental or scholastic or political authority. I submit that there were genuine objective problems that would go beyond and could not be easily solved in terms of a simplistic "generation gap theory". It is true, however, that the movement of 1968, for all its vocal propositions, was not able to last nor succeed in conducting a cold, realistic analysis of the power structures it intended to attack and eventually demolish. In fact, its final result consisted paradoxically and quite unintendently in a reinforcement of the vested interests and in general of the existing "establishment". ${ }^{12}$

Since the very beginning of the movement it was perhaps easy to see that the violent methods, would have had a boomerang effect on the general public opinion; in other words, that the effects of the ' 68 movement would by far exceed and go beyond the academic world.

Although the political aim and the acquisition of power in the name of counter-power or no-power were loudly voiced, it was clear at the very outset that politics would not have been the only field of the movement, nor perhaps the most important one. In this respect, dialectic between young and adults was early caught by a shrewd observer: "Many students exhibited their renunciation of the culture of their parents through innovative forms of dress, hairstyles, use of drugs, obscos language, and more widespread willingness to have a variety of sexual experiences... And many adults who could accept revolutionary politics as the idealism of young people who would grow more conservatively as they grew older, a frequently made observation about student radicals in many countries, found themselves horrified by the new morality of renunciatory segment of the young".

It is, however, difficult to deny a link of the '68 movement of contestation with the individualistic denunciation of machine-based civilization by a man like Thoreau. Nothing and nobody seem farther from the aloof anarchist of Walden than the obstreperous, rambunctious and at times cheerfully joyous movement of the students marching, for instance, along Boulevard Saint-Gernain des Pres, common thread, however, becomes quite visible when they pretend to have "imagination in power" or claim to invent a "new way to manufacture more cars" or finally pretend to have a care center for their infants in the premises of "La Sorbone". Looking retrospectively farther back, it is impossible to deny some sort of kingship or at least intermittent congeniality between the movement of ' 68 and the anti-machines temper during the

${ }^{12}$ In this respect, see my L'Italia in bilico, Bari 1991, passim but especially the "Apendix". 
early phases of the "Industrial revolution" in its double aspect, as a popular revolt against machinery as a labor-saving devices, and as an aristocratic myth, such as in John Ruskin, Unto this Last ${ }^{13}$, that is as a polemical feeling against machinery by people who, because of their privileged station in life, could not possibly have any familiarity with industrial machines.

Elsewhere I have dealt extensively with anti-machine feeling as a protest. ${ }^{14}$ In its crudest from this protest is traditionally called "Luddism". It takes its name from the English worker Ludd, who failing to win a dispute with the workers of a shoe factory, directed his anger on the factory's machines. The first group of Luddites made its appearance in Nottingham in 1811, and a deep vein of anti-machines feeling has generally distinguished the early phases of the modern workers movement. Their machine-breaking fury needs no ideological or doctrinal justifications. It explodes with the natural and violent readiness of legitimate defense. The machine condemns the worker to unemployment and poverty. Furthemore, with the machines the impersonal and anonymous discipline of "work rules" substitute paternalism which, although authoritarian, is still human. The old-faschioned employer, who chose the best workers from the most lively boys of his parish, is succeeded by the arrogant university-educated engineer.

\section{Science, for what? Or: science with conscience - the invisible college of dissenting nuclear scientists.}

The polemical reaction against science and scientific reasoning is nothing new. When small industries, developed in the old regime as a sort of complementary activity to large-scale landowning, grow and enlarge their field of operations until they give way to the first accumulation of capital and make large - scale mechanization technically possible and economically convenient, the consequences for the whole way of life and "culture" are immediate and profound. Here a more pervasive anti-feeling arises and develops in two different directions which could perhaps be called the mystique of craftmanship and the refusal of the modern scientific world. The "mystics of craftsmanship" are not anti-technology on principle; they accept technical progress with reservations. They recognize the advantages of technical progress but fear that the price to pay is too high. They propose decentralization, they preach against the mania for the colossal and big size in all its aspects. Their most coherent historical representative is the French libertarian socialist or, perhaps more precisely, anarchist Pierre - Joseph Proudhon.

Other groups are more extreme and collide head-long with the modern world as the world in which, to use the famous title of Siegfried Gideon, "mechanization takes

\footnotetext{
${ }^{13}$ Cfr. Seymour M. Lipset, Rebellion in the University, London, 1972,p.16.

${ }^{14} \mathrm{Cfr}$, my The Myth of Inevitable Progress, New York, 1985, pp. 26-27.
} 
command". Despite the intellectual refinement of those groups, one can easily detect in them overtones of medieval and decadent nostalgia. The romantic German poet Novalis had already noticed the damage that, in his judgment, science was doing to the "sense of the invisible". But even present day sophisticated writers such as Dwight MacDonald, seem to share the romantic tendency to downgrade the scientific mind.

"We Americans - MacDonald writes- are hunters rather than artists, men of action rather than of thought or feeling. Our chief contribution to philosophy is pragmatism...; technique rather than theory distinguishes our science, our homes, our cities, our landscapes are designed for profit or practicality but not generally for beauty. We think it odd that a man should devote his life to writing poems but natural that he should devote it to inducing children to breakfast on Crunchies instead of Krispies. Our scholars are strong on research weak on interpreting the masses of data they collect". ${ }^{15}$ This is, according to MacDonald, the "Triumph of the Fact" that is brought about by a dominant scientific attitude.

It seems clear that we have here an emblematic example of the confusion between science and its popular caricature that is "scientism". This pathetic error, although widespread, to the point of considering science as a kind of mysterious and allpowerful magic art, is also due, at least in part, to scientific propagandists who tend to see in science and in scientific research the cure for all the evils of the world. From such commonplaces the scientist emerges as a new saint, the saint of the industrial age of mass technology. Science itself is conceived and presented as a new religion. It is seriously stated that science, given its head, is not just mechanical efficiency, its attitude is tolerant, friendly and humane. It has already become - it is maintained - the dominant inspiration of human culture, so that modern poetry, painting and architecture derive their most constructive ideas from scientific thought.

This dytirambic mood goes as far as ignoring simple facts that are connected with obvious scientists' responsibility. Twenty years before C.P.Snow, the celebrated author of The Two cultures and the Scientific revolution (London,1962), C. H.Waddington takes the love for peace on the part of the scientists for granted: "Far from considering war as the highest activity of man... scientists, even more than most people in this country (England), find it a damnable, if unavoidable, interruption of their serious business. For science is concerned with man's real evolutionary advance, with giving him the mastery over things which will enable him to translate his wishes and aspirations into

${ }^{15}$ Cfr. Dwight MacDonald, Against the American Crain, New Yor,, 1952, p.426; see also my Scienza e coscienza, Bologna, CED, 2014. 
fact" ${ }^{16}$ Too bad, one may add, that scientists have also provided politicians with the most powerful and deadly means of mass destruction.

Quite unexpectedly, it is among the most advanced scientists, among some specialists of nuclear physics, that the reaction against the practice of scientific research as a neutral, purely instrumental activity- a kind of perfection without purpose- is formed at first and then, little by little, developed. The most eloquent and telling example of positive counter- culture movement is not, therefore, to be looked for among to the vociferous "revolutionary" students, but among dedicated researchers and top level scientific, from Robert Oppenheimer to Andrei Sakharov. In their different ways these scientists have organized through the years, since the end of the second world war, some sort of "invisible college". The function of this college has been to work in the scientific laboratories as well as in close contact with public opinion at large in order to turn the resources of nuclear energy away from war programs to peace activities and practical application in various fields, from medicine to electricity production. In the early days of the "Bulletin of Atomic Scientists" one realizes that the scope of such initiatives is extraordinarily broad. To the groups of dissenting scientists, centering around the "Bulletin", not only physicists but also social analysts such as Edward A. Shils and David Riesman, would actively participate.

The contribution of nuclear physicists to the peaceful use of nuclear energy has been outstanding in terms of its impact on public opinion as regards the technical aspects of the issue. But in some cases this contribution has turned into a political struggle in the proper sense, notably in the experience of Andrei Sakharov and his wife, Jelena Bonner. While Leonid Brezhnev was in power in the former Soviet Union, the Sakharovs were exiled and forced to leave Moscow in order to settle down in Gorki, where their visibility, especially in the eyes of foreign public opinion through newspapers and television networks, was drastically diminished. In some cases, the opposition to the use of nuclear energy for war purposes was less conspicuous but nonetheless constant and, to an extent, courageous. Robert J. Oppenheimer, the director of the Alamos Project during war time, refused to support the construction of the Hydrogen Bomb on technical grounds, citing practical difficulties, if not a sheer theoretical impossibility. Dr. Oppenheimer was in fact hiding his personal moral scruples behind some technicalities. He went to the point of resigning his important government post. A less morally sensitive colleague, Dr. Edward Teller, would eventually build the Hydrogen Bomb.

\footnotetext{
${ }^{16}$ Crf.C.H.Waddington, The Scientific Attitude, London, 1941, p.190.C.P.

Snow was also preceded by scholars such as James Harvey Robinson, The Humanizing of Knowledge, New York, 1923, p. 81 : "Those who devote their professional lives to literature can probably look back to the vain efforts of their awkward teachers of science to adorn them with a bad or two form Science's iris-hued brush and their lasting resentment at the attempt to discolor their poetic or romantic souls. In later life they compensate themselves for their gross ignorance of natural processes by declaring, as Mr. Chesterton does, that science is irrelevant to our deeper lives; or as Brunetière did, that science is bankrupt".
} 
Given the crucial importance of their work, it is no wonder that a cloud of doubt has always loomed large on the loyalty of the whole category of nuclear scientists. The situation was made worse by the inevitable internal dissensions among scientists. Only naïve commentators could in fact imagine that scientific progress unfolds according to a smooth, harmonious and self-correcting logic of development. The autobiography of Emilio Segre, an important collaborator of Enrico Fermi since the early days of the "Via Panisperna Boys" in Rome, proves once more that coldblooded and self-controlled scientists also are passionate human beings and can have sentiments of warm sympathy as well as of profound dislike for other human beings. ${ }^{17}$

The Nobel Prize Emilio Serge states flatly in his book that the relationships among scientists, especially among physicists, far from being idyllic, are usually "veiled by a reciprocal doubt of suspicions". Segre is particularly bitter and, it seems, unfair towards Robert J. Oppenheimer, whom he found not only unsympathetic but also "slightly ridiculous". Naturally his term of comparison was the towering figure of Enrico Fermi, "a man of great solidity, whose simplicity was in stark contrast with the elaborated and complicated erudition of Oppenheimer". Segre has also something to say about the Oppenheimer group, whose average cultural level, in his opinion, "was somewhat below the level of European high school students".

It would be wrong, however, to reduce the internal frictions among these scientists to purely personal idiosyncrasies or psychological feelings. The very fact, that nuclear physicists were dealing with the construction of secret and powerful weapons, would expose them to the traps and temptations of the spy rings East and West. The recent book by Pavel Sudoplatov and Anatoli Sudoplatov ${ }^{18}$ is, in this respect, an important, although controversial contribution. Its main thesis is that scientists such as Oppenheimer, Fermi, Szilard and Rabi were manipulated and used by Soviet intelligence. This might be a gross exaggeration but it is well-known on the other hand that at least some prominent scientists in the West thought at one time that passing atomic secrets to the Soviet Union would have helped to keep peace in the world through a relative nuclear balance between East and West. ${ }^{19}$ In a sense, I submit that especially in the years immediately before the cold war when Western Allies still felt that the Soviet Union was a reliable partner in the struggle against Nazism and Fascism, disclosing classified information was regarded more as a counter-culture move, more or less ideologically inspired, than a spy initiative.

In this connection one cannot help admiring the sober attitude of Andrei Sakharov. Confronted with immediate danger of persecution by the Soviet authorities, Sakharov

\footnotetext{
${ }^{17}$ Cfr. E. Segre, A Mind Always in Motion, University of California Press, 1994.

${ }^{18}$ Crf. P. Sudoplatov, A. Sudoplatov, Special Tasks, New York, 1994.

${ }^{19}$ See the interesting polemical exchange, "Were the Atom Scientists Spies", in The New York rewiew of Books, September 22, 1994, pp.72-74.
} 
was nevertheless adamant in defending the cause of peace and international understanding. What seems to me, at this point, most admirable is the sense of measure and of balanced judgment he showed time and again. Devoted as he was to the cause of disarmament, even of unilateral disarmament, if necessary, he never gave up the idea of nuclear testing as the only means to assess scientifically the impact of the new weapon technology by either side. At the "Forum for a Nuclear Free World", held in Moscow 1987, Sakharovs reported to have said: "...The question of nuclear testing is not critical for the restraint of the arms race. The issue of nuclear testing, in my opinion, is of minor, secondary importance in comparison with the other military, technical, political and diplomatic problems involved in preventing thermo-nuclear calamity...I believe that eliminating the issue of a comprehensive nuclear test ban will facilities negotiating on more urgent problems of disarmament". ${ }^{20}$ Thus, we have come a long way. In approximately two centuries, from the anarchist Kropotkin to the scientist Sakharov, the counter-culture movement has come of age. It is no longer to be confused with the grandiose, but highly unrealistic, dream of totally liberated world through a cathartic revolution and a consequent palingenesis, but it rather emerges as a piece-meal transformation which is constantly under the control of the community judgment in order to strike the best connection between what is ideally desirable and what is today already possible.

${ }^{20}$ Cfr. A. Sakharov, "Of Arms and Reforms", in Time Magazine, March 16, 1887. 